\title{
Gelatin supports with immobilized laccase as sustainable biocatalysts for
}

\section{water treatment}

Marine Harguindeguy, Claire Antonelli, Marie-Pierre Belleville, José Sanchez-Marcano,

Céline Pochat-Bohatier*

Institut Européen des Membranes, IEM UMR 5635, Univ Montpellier, CNRS, ENSCM, Place Eugène Bataillon, 34095 Montpellier cedex 5, France

*Corresponding author

Institut Européen des Membranes, IEM UMR 5635, Univ Montpellier, CNRS, ENSCM, Montpellier, France.

E-mail : celine.pochat@umontpellier.fr, Tel : 33 (0)467 143327

E-mail addresses : marine.harguindeguy@umontpellier.fr (M. Harguindeguy),

claire.antonelli@umontpellier.fr (C. Antonelli), marie-pierre.belleville@umontpellier.fr (MP Belleville), jose.sanchez-marcano@umontpellier.fr (J. Sanchez-Marcano)

\section{ABSTRACT}

Millimeter-size beads of gelatin are manufactured by dripping process to give enzyme supports qualified for micropollutants biodegradation in alternative wastewater treatment. The bead diameter is dependent on the tip diameter, the gelatin solution viscosity and the 
swelling of polymer chains in the collecting bath. Chemical cross-linking was performed with glutaraldehyde using optimal concentration to give mechanical and thermal properties suitable for application in stirred reactor in aqueous medium. Laccases from Trametes versicolor are grafted on the gelatin beads with glutaraldehyde. $60 \%$ of the initial enzymatic activity, evaluated by the oxidation of 2'-Azino-bis(3-ethylbenzothiazoline-6-sulfonic acid)diammonium salt (ABTS) is maintained after 10 successive cycles of reaction. Thermal stability at $60^{\circ} \mathrm{C}$ of immobilized biocatalysts is improved when compared to free enzymes ( $45 \%$ vs $10 \%$ of relative activity after 6 hours of incubation). The simplicity of the procedure to form gelatin beads and their properties make them promising bio-based and biodegradable support for enzyme immobilization.

KEYWORDS: Gelatin beads; biocatalysts; Enzyme immobilization; Laccase

\section{INTRODUCTION}

The interest of enzymatic reactions in industrial applications has been increased in recent years because the use of biocatalysts results in green processes which can be carried out without organic solvents and at mild conditions. ${ }^{1,2}$ Different areas can benefit from enzymatic bioprocesses due to the high specificity and selectivity of enzymes. They include pharmaceutical, $^{3,4}$ food, $^{5,6}$ cosmetic industries ${ }^{7}$ and environmental applications. ${ }^{8,9}$ Nevertheless, the main drawback for full development of enzymatic processes concerns the biocatalyst separation and its reusability which affects the operation costs. The immobilization of enzymes onto a support allows the biocatalyst reuse and enhances its stability. ${ }^{10}$ Efficient immobilization, avoiding enzyme leaching, is achieved on support 
displaying numerous functional groups, large surface area, biocompatibility, no toxicity, and good structural and mechanical stability. ${ }^{11}$ Different supports have been studied and applied at industrial scale from inorganic supports like silica, ${ }^{12}$ inorganic oxides, ${ }^{13}$ minerals, ${ }^{14}$ to organic materials as biopolymers ${ }^{15}$ or synthetic polymers, ${ }^{16}$ and even hybrid materials. ${ }^{17}$

Biopolymers like alginate and chitosan are frequently used for enzyme immobilization due to their interesting properties which include biocompatibility, high biodegradability, absence of toxicity and relatively low cost. ${ }^{15,18,19}$ Gelatin brings all these properties and allows enzyme immobilization by encapsulation or entrapment. ${ }^{20-22}$

Gelatin microspheres can be prepared by emulsification, ${ }^{23}$ electrospinning, ${ }^{24}$ spray drying, ${ }^{25}$ oil-in-water emulsion ${ }^{26,27}$ and water-in-water emulsion. ${ }^{28}$ From our knowledge, no study has been already reported on the preparation of millimeter-size beads by dripping in a gelation bath for gelatin. However, dripping process is a very simple process to implement; it has been widely used to prepare alginate beads for various applications. ${ }^{28-30}$

This paper presents the operating conditions to design biocatalysts made by immobilized laccases onto gelatin beads for applications related to wastewater treatment. The formation mechanism of the beads is based on the coacervation of gelatin droplets in polyethylene glycol solution. The protein precipitate in the nonionic polymer because of excluded volume effect on gelatin. ${ }^{31}$ The beads are then used as support for the covalent immobilization of a commercial laccase from Trametes versicolor. This enzyme is able to oxidize a broad variety of substrates using only oxygen as co-substrate and is suitable for environmental remediation by degrading micropollutants in water. ${ }^{32,33}$ As long term stability in water and mechanical resistance to shear stresses is required, conditions of beads cross linking is studied and additional material characterizations (swelling capacity, thermal property) are 
carried out to evaluate sustainability of gelatin beads in aqueous solutions. Finally, laccase are grafted and enzymatic activity and stability of biocatalysts obtained are studied using ABTS oxidation as model reaction for micropollutant biodegradation.

\section{EXPERIMENTAL}

\section{Materials}

Gelatin porcine skin type A ( $M W \sim 50-100 \mathrm{KDa}$, bloom 300) (CAS 9000-70-8), polyethylene glycol (PEG with molecular weight 5, 10, 20, $35 \mathrm{KDa}$ are denoted $\mathrm{PEG}_{5}, \mathrm{PEG}_{10}, \mathrm{PEG}_{20}$ and $\mathrm{PEG}_{35}$ respectively) (CAS 25322-68-3), glutaraldehyde aqueous solution grade $\|\left(25 \% \mathrm{w}_{\mathrm{t}}\right.$ in $\mathrm{H}_{2} \mathrm{O}$, CAS : 1111-30-8), laccase (from Trametes Versicolor, CAS 80498-15-32), 2'-Azino-bis(3ethylbenzothiazoline-6-sulfonic acid)diammonium salt (CAS 30931-67-0) (ABTS), 2,4,6Trinitrobenzenesulfonic acid solution (TNBS) (5\% w/v in $\mathrm{H}_{2} \mathrm{O}$, CAS 2508-19-2), hydrochloric acid (37\% $\mathrm{w}_{\mathrm{t}}$ in $\mathrm{H}_{2} \mathrm{O}$, CAS $\left.7647-01-0\right)$, and borax solution $(5 \mathrm{~g} / \mathrm{dl}$ in deionized water) are of ACS reagent grade and purchased from Sigma-Aldrich. Buffer solutions are prepared from citric acid (CAS 77-92-9), and di-sodium hydrogen phosphate dihydrate (CAS 10028-24-7).

\section{Beads elaboration}

A proper amount of gelatin is added to $30 \mathrm{~g}$ of water in order to achieve final concentrations of $15,18,20$ and 22 wt-\%; the suspension is heated and let to dissolve at controlled temperature $\left(60^{\circ} \mathrm{C}\right)$ during $2 \mathrm{~h}$. PEG solutions of diverse molecular weights $(5,10,20,35 \mathrm{KDa})$ are prepared in distilled water at a concentration of $40 \% \mathrm{w} / \mathrm{v}$. They are let to mix during the whole night at $50^{\circ} \mathrm{C} . \mathrm{PEG}_{10}$ solutions with various concentrations $(20 \%, 30 \%, 40 \%, 50 \% \mathrm{w} / \mathrm{v})$ are formulated using the same procedure. The dripping process is carried out by adding dropwise a gelatin solution into a polyethylene glycol solution at $50^{\circ} \mathrm{C}$ via a SP200 syringe pump (flow rate: $4 \mathrm{~mL} \mathrm{~min}^{-1}$ ). The low affinity between gelatin and PEG allows the droplets 
to keep their bead shape because gelatin does not mix with PEG. Freezing of the droplets is then carried out by immersion in an ice bath at $5^{\circ} \mathrm{C}$ so that the gelatin beads undergo a fast gelation. Afterward, they are taken away from the solution and washed thoroughly with water to remove residual traces of PEG. Figure 1 sums up the steps of the elaboration of gelatin beads.

a)

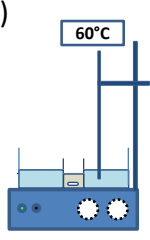

b)

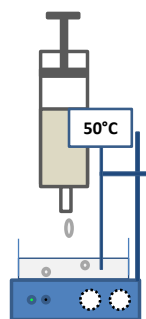

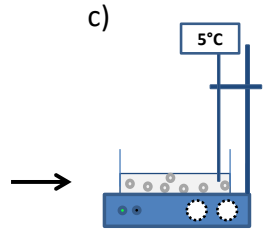

FIGURE 1: Steps of bead elaboration: (a) dissolution of the gelatin solution at $60^{\circ} \mathrm{C}$ during $2 \mathrm{~h}$, (b) dripping of gelatin solution by means of an automatic syringe into polyethylene glycol bath at $50^{\circ} \mathrm{C},(\mathrm{c})$ beads cooling at $5^{\circ} \mathrm{C}$ in an ice-bath to induce fast gelation.

\section{Rheological measurements}

The viscosity of gelatin and PEG solutions is measured by the means of a MCR 301 rheometer (Anton Paar) using a cone-and-plate geometry (diameter $50 \mathrm{~mm}$, angle $1^{\circ}$ ). The measurements are carried out at $60^{\circ} \mathrm{C}$ for gelatin solutions and $50^{\circ} \mathrm{C}$ for PEG solutions, with a constant shear rate of $500 \mathrm{~s}^{-1}$.

\section{Theoretical determination of beads diameter}

The size of the beads obtained by dripping technique can be predicted by using the work of Kamaruddin et al (2014), based on Tate's law, with Equation 1, where $\mathrm{d}_{\mathrm{T}}$ is the tip diameter $\left(0.27 .10^{-3} \mathrm{~m}\right), \gamma$ the gelatin surface tension $\left(41 \mathrm{mN} \cdot \mathrm{m}^{-1}\right.$ at $\left.60^{\circ} \mathrm{C}\right), \rho$ the gelatin solution density 
$\left(\mathrm{kg} \cdot \mathrm{m}^{-3}\right), \mathrm{g}$ the gravitational constant $\left(9.81 \mathrm{~m} \cdot \mathrm{s}^{-2}\right), \mathrm{K}_{\mathrm{LF}}$ the liquid lost factor, and $\mathrm{K}_{\mathrm{SF}}$ the shrinkage lost factor. ${ }^{29,34}$

$$
d_{p}=K_{S F} K_{L F}\left(\frac{0.06 d_{T} \gamma}{\rho g}\right)^{\frac{1}{3}}
$$

$\mathrm{K}_{\mathrm{LF}}$ was demonstrated to be only dependent to the tip size, and not to the liquid properties, and can be determined using Equation 2.

$$
K_{L F}=2.471-1.926 * d_{T}
$$

$\mathrm{K}_{\mathrm{SF}}$ is the shrinkage factor and corresponds to the ratio between the diameter of the bead before and after gelation.

\section{Cross-linking and activation of gelatin beads}

The beads are immerged in an aqueous glutaraldehyde (GTA) solution under magnetic stirring (250 rpm), during 1 hour at $25^{\circ} \mathrm{C}$. They are then filtered and thoroughly washed with

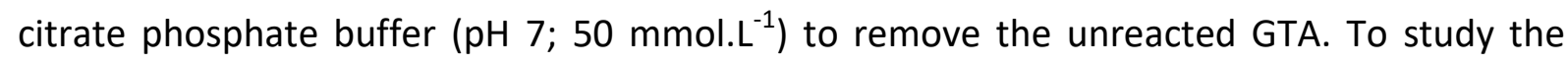
influence of GTA concentration on the cross linking ratio, several solutions are prepared: $0.025 ; 0.05 ; 0.1 ; 0.3 ; 0.5 ; 1 ; 2 ; 3 ; 4$ and $5 \% \mathrm{v} / \mathrm{v}$.

Cross-linked beads are then immerged in a solution of laccase (Trametes Versicolor) ( 3 U. $\left.\mathrm{mL}^{-1}\right)$ prepared in a citric phosphate buffer solution $\left(\mathrm{pH} 7 ; 50 \mathrm{mmol} . \mathrm{L}^{-1}\right.$ ) during 2 hours at $25^{\circ} \mathrm{C}$ under magnetic stirring $(250 \mathrm{rpm})$. The beads are once again washed thoroughly with buffer solution $(3 \times 50 \mathrm{~mL})$ to remove the enzymes that have not been immobilized on the surface.

\section{Activity assay of laccases and kinetics constants determination}

The activity of free and immobilized laccase is determined using a colorimetric assay based on the oxidation of ABTS. $900 \mu \mathrm{L}$ of ABTS $\left(1 \mathrm{mmol}^{-1}, \mathrm{pH} 4\right)$ are mixed with $100 \mu \mathrm{L}$ of enzymatic solution (for free enzyme) directly inside a spectrophotometric cell and the 
reaction is monitored with a spectrophotometer Shimadzu UV-2401 PC at $420 \mathrm{~nm}$ along with the software UV Probe version 2.21. One unit of enzyme activity is defined as the amount of enzyme that converted $1 \mu \mathrm{mol}$ per minute of ABTS to its cation radical at $\mathrm{pH} 4$ and $25^{\circ} \mathrm{C}$. The optical density (or absorbance) can be linked to the amount of enzyme with the Beer Lambert law :

$$
O D=\varepsilon * l * c
$$

with $\varepsilon$ the molar extinction coefficient $\left(0.036 \mathrm{~L} . \mu \mathrm{mol}^{-1} . \mathrm{cm}^{-1}\right), \mathrm{I}$ the optical path length $(1 \mathrm{~cm})$. In the case of immobilized enzymes, $0.7 \mathrm{~g}$ of active beads are immerged in $25 \mathrm{~mL}$ of ABTS solution (1 mmol. $\left.\mathrm{L}^{-1}, \mathrm{pH} 4\right)$ and the absorbance of the solution is monitored every minute during 15 minutes. The slope of the curve is then used to determine the rate of ABTS conversion and thus is directly related to enzymatic activity $(A)$.

The immobilization yield $\left(\eta_{i m}\right)$ was determined (equations 4 and 5 ) by taking into account the enzymatic solution activity before $\left(A_{i}\right)$ and after grafting $\left(A_{f}\right)$, as well as the sum of the activity of the washing solutions $\sum \mathrm{A}_{w}$.

$$
\begin{gathered}
\mathrm{A}_{\text {im }}=\mathrm{A}_{i}-\left(\mathrm{A}_{f}+\sum \mathrm{A}_{w}\right)(4) \\
\eta_{\text {im }}=\frac{\mathrm{A}_{\text {imtheo }}}{\mathrm{A}_{i}} * 100(5)
\end{gathered}
$$

$\mathrm{A}_{i m}$ : Theoretical immobilized enzymes activity

The expressed activity $A_{\text {exp }}(\%)$ is defined by the ratio between the experimental immobilized enzymes activity $A_{\text {im } \exp }$ (determined by ABTS assay) on the initial enzymatic activity (equation 6) :

$$
A_{\text {exp }}=\frac{A_{\text {im exp }}}{A_{i}} * 100(6)
$$


The $\mathrm{pH}$ profiles of the free and immobilized enzymes were determined by measuring the enzymatic activity at $25^{\circ} \mathrm{C}$, with 1 mmol. $\mathrm{L}^{-1} \mathrm{ABTS}$ solutions prepared at $\mathrm{pH} 2.2-3-4-5-6$ (in citrate phosphate buffer, $50 \mathrm{mmol}^{-1}$ ). The temperature profiles of the free and immobilized enzymes were determined by measuring the enzymatic activity, with $1 \mathrm{mmol} . \mathrm{L}^{-1}$ ABTS solutions prepared in a phosphate citrate buffer solution $(50 \mathrm{mM}, \mathrm{pH} 4)$ at different temperatures : $20-25-35-45-55^{\circ} \mathrm{C}$.

Maximal enzymatic activity found of immobilized enzymes and free enzymes was considered as reference value of $100 \%$. Those experiments were carried out in triplicate and the average value is displayed.

The apparent kinetic parameters of Michaelis-Menten equation $\left(K_{m}\right.$ and $\left.V_{\max }\right)$ of free and immobilized laccases are determined from initial reaction rates in batch experiments. ABTS solutions of $10-15-25-50-100 \mu \mathrm{mol}^{-L^{-1}}$ are prepared in a citrate phosphate buffer solution $\left(50 \mathrm{mmol} . \mathrm{L}^{-1}, \mathrm{pH}\right.$ 4). The reactions are carried out at $25^{\circ} \mathrm{C}$, with a concentration equivalent to 30 U.L $L^{-1}$ for both immobilized and free enzymes.

\section{Thermal stability and reusability of the supports}

Thermal stability of the free and immobilized enzymes is evaluated by incubating the samples at $60^{\circ} \mathrm{C}$ for 6 hours. The activity is measured with ABTS as substrate $\left(50 \mathrm{mmol.L^{-1 }}\right.$; $\mathrm{pH} 4)$ at $25^{\circ} \mathrm{C}$ at different time intervals. Enzymatic activity of immobilized enzymes and free enzymes is measured before incubation and is considered as reference value of $100 \%$. The experiment is carried out in triplicate and the average value is displayed.

To determine the reusability of the supports, $0.64 \mathrm{~g}$ of active beads at an enzymatic equivalent of $60 \mathrm{U.L}^{-1}$ is let to react with $25 \mathrm{~mL}$ of $A B T S\left(1 \mathrm{mmol.L}{ }^{-1}, \mathrm{pH} 4,25^{\circ} \mathrm{C}\right)$ during 10 cycles of 15 minutes. Between each cycles, the beads are washed thoroughly with $50 \mathrm{~mL}$ of 


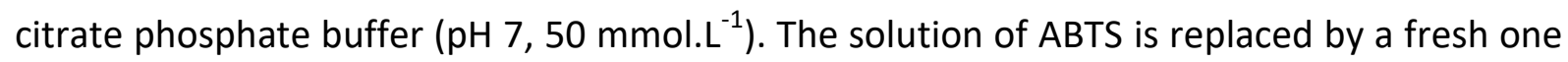
at the end of each cycle. The initial activity was considered as reference value of $100 \%$.

\section{Bead characterizations}

\section{FT-IR analysis}

Infrared spectra are recorded on a Nicolet 710 Fourier-transform infrared (FTIR) spectrometer, using a Thermo-Electron attenuated total reflectance (ATR) accessory with a diamond crystal. For each spectrum, 128 scans are collected with a resolution of $4 \mathrm{~cm}^{-1}$.

\section{Crosslinking ratio determination}

In order to evaluate the influence of the GTA concentration for a given reaction time on the crosslinking ratio, determination of the number of residual amino groups in gelatin after crosslinking is carried out. ${ }^{35,36} 1 \mathrm{mg}$ of cross-linked gels (with different concentrations of GTA) are solubilized in $1 \mathrm{~mL}$ of Borax during 3 hours at $60^{\circ} \mathrm{C}$. Then, $1 \mathrm{~mL}$ of $1 \% \mathrm{v} / \mathrm{v}$ TNBS solution is added, and the solutions are stirred and heated at $60^{\circ} \mathrm{C}$ during $2 \mathrm{~h} 30.3 \mathrm{~mL}$ of $\mathrm{HCl}$ $\left(1 \mathrm{~mol} . \mathrm{L}^{-1}\right)$ are added to stop the reaction. After 30 minutes, the solutions are diluted ten times and the absorbances are measured with the spectrophotometer Shimadzu UV-2401 PC at $347 \mathrm{~nm}$. The absorbance of two controls is also measured: one sample of uncrosslinked gelatin $\left(\mathrm{Abs}_{\mathrm{G}}\right)$ prepared in the exact same way as described before, and one sample of TNBS/Borax/ $\mathrm{HCl}\left(\mathrm{Abs}_{\mathrm{TNBS}}\right)$. The crosslinking ratio is calculated according to Equation 8.

$$
\text { Cross linking ratio }=100 *\left[1-\frac{100 *\left(A b s-A b s_{G}\right)}{A b s_{G}-A b s_{T N B S}}\right]
$$

3 replicates are carried out for each sample and the average value is reported.

\section{Swelling ratio}

Gelatin beads (uncross-linked and cross-linked at various concentrations of GTA), are dried in a desiccator under silica gel for 48 hours until they reach a constant weight $\left(w_{d}\right)$. Beads are then immerged in $15 \mathrm{~mL}$ of distilled water at $25^{\circ} \mathrm{C}$. From this point, the gels are weighed at 
different times $\left(w_{t}\right)$ with a Precisa XB 320 M precision balance to see the evolution of the swelling ratio (SW (\%), Equation 9). Each experiment is carried out by triplicate and the average value is reported.

$$
S W(\%)=\frac{w_{d}-w_{t}}{w_{d}} * 100
$$

\section{Mechanical properties}

Gelatin solutions of several concentrations are poured in cylindrical molds. After 4 hours at room temperature, hydrogel cylinders are then sliced into small samples $(0.8 \mathrm{~cm}$ of diameter, $2 \mathrm{~cm}$ of height). A part of the samples are cross-linked with GTA $(0.5 \%, 1 \%, 2 \%$, $3 \%, 4 \%, 5 \% \mathrm{v} / \mathrm{v}$ ) during 1 hour at $25^{\circ} \mathrm{C}$.

Uniaxial compression tests are carried out with a dynamic mechanical analysis system (Metravib, 50dB), equipped with the software Dynatest 6.93. Both cross-linked and uncrosslinked hydrogels are tested and are compressed at a speed rate of $10^{-5} \mathrm{~m} \cdot \mathrm{s}^{-1}$ using a $40 \mathrm{~N}$ load cell. The young modulus $E$, the stress at break $\sigma_{b}$ and the strain at break $\varepsilon_{b}$ are determined. Measurements are carried out with 5 replicates and the mean data are given.

To evaluate the beads resistance in water, the gels are dipped in $15 \mathrm{~mL}$ water and the same tests are carried out at different times after immersion. The apparatus was turned upside down so that the gels are immersed in water even during the tests (Figure 2).

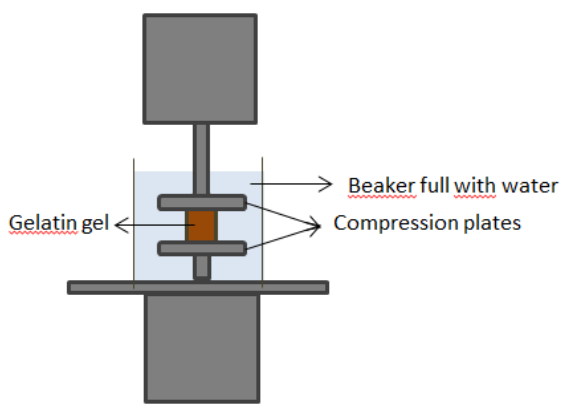

FIGURE 2: Dynamic mechanical analysis in immersion mode

\section{Thermal analysis}


Thermal properties are determined both on pristine and crosslinked gelatin beads. Their degradation temperature and residual humidity are measured by thermogravimetric analysis (TGA) carried out on a TA Instruments TGA G500 under nitrogen flow of $60 \mathrm{~mL} \cdot \mathrm{min}^{-1}$. The samples are heated from $20^{\circ} \mathrm{C}$ to $1000^{\circ} \mathrm{C}$ at a heating rate of $10^{\circ} \mathrm{C} \cdot \mathrm{min}^{-1}$. The gels are then analyzed with a differential scanning calorimeter DSC 2920 equipped with cooling accessory RCS90 (TA Instruments). The samples (around $3 \mathrm{mg}$ ) are sealed in aluminum TA pan. The instrument is calibrated with pure indium and used an empty pan as reference. The gels are heated from $-40^{\circ} \mathrm{C}$ to $200^{\circ} \mathrm{C}$ at a $20^{\circ} \mathrm{C} \cdot \mathrm{min}^{-1}$ heating rate. The value given for each sample is an average of 3 replicates.

\section{RESULTS AND DISCUSSION}

\section{Beads elaboration}

The first experiments are conducted by dripping a gelatin solution of $22 \mathrm{wt}$ - $\%$ in a coagulation bath made with $\mathrm{PEG}_{10}$ solution with a concentration ranging from 20 to 50 wt-\% (Table 1). 
TABLE 1: Influence of $\mathrm{PEG}_{10}$ concentration on the gelatin beads formation; [gelatin] = $22 \mathrm{wt}-$ $\%$.

\begin{tabular}{c|c|c|c|c}
\hline $\begin{array}{c}\text { Concentration } \\
(\% \mathrm{w} / \mathrm{v})\end{array}$ & 20 & 30 & 40 & 50 \\
\hline Observations & $\begin{array}{c}\text { Non spherical } \\
\text { beads }\end{array}$ & $\begin{array}{c}\text { Non spherical } \\
\text { beads }\end{array}$ & Spherical beads & $\begin{array}{c}\text { Droplets } \\
\text { blocked at the } \\
\text { surface }\end{array}$ \\
\hline $\begin{array}{c}\text { characteristic } \\
\text { length (mm) }\end{array}$ & $5.0 \pm 0.75$ & $2.7 \pm 0.11$ & $1.9 \pm 0.19$ & N/A \\
\hline
\end{tabular}

At relatively low $\mathrm{PEG}_{10}$ concentrations $(20 \%$ and $30 \% \mathrm{w} / \mathrm{v})$, the beads formed are not spherical. Sphericity is improved when the concentration is increased $(40 \% \mathrm{w} / \mathrm{v})$ and the characteristic length of the objects is $1.9 \mathrm{~mm}$. If $\mathrm{PEG}_{10}$ is too concentrated $(50 \% \mathrm{w} / \mathrm{v})$, the droplets remain attached at the surface. This behavior can be explained by taking into consideration both physical-chemical and kinetics aspects. First, PEG and gelatin do not display affinity because of large excluded-volumes and the absence of acidic sites on PEG to interact with gelatin. When the concentration increases, the PEG chains are more numerous and closer from each other enhancing the exclusion phenomena between the polymer and the protein. ${ }^{37}$ Higher PEG $_{10}$ concentration favors protein folding to form beads of smaller diameter. ${ }^{38}$ Secondly the velocity of gelatin droplets inside the $\mathrm{PEG}_{10}$ solution (visual observation) decreases with the rising of PEG concentration, limiting the deformation of droplets along the phase separation process. However, for high concentration of PEG (at $50 \% \mathrm{w} / \mathrm{v})$, the droplet do not penetrate into the solution. Therefore, a concentration of $40 \%$ $\mathrm{w} / \mathrm{v}$ was chosen. These preliminary experiments lead us to take also into consideration the viscosity of the solutions for further assays. 
The impact of the bath formulation is then investigated, by modifying the size of PEG. Four different PEGs showing molecular weight (Mw) of 5, 10, 20 and $35 \mathrm{kDa}$ are tested and the characteristics of the beads obtained are reported in Table 2 .

TABLE 2: Influence of the PEG molecular weight $\left(M_{w}\right)$ on the PEG solution viscosity $(\eta)$ and gelatin beads formation; $[\mathrm{PEG}]=40 \% \mathrm{w} / \mathrm{v}$, [gelatin] $=22 \mathrm{wt}-\%$, gelatin viscosity at $60^{\circ} \mathrm{C}=133$ mPa.s.

\begin{tabular}{|c|c|c|c|}
\hline $\begin{array}{l}\text { PEG } M_{w} \\
(K D a)\end{array}$ & $\begin{array}{l}\text { PEG } \eta \\
\text { (mPa.s) }\end{array}$ & Gelatin beads formation & $\begin{array}{l}\text { Beads diameter } \\
(\mathrm{mm})\end{array}$ \\
\hline 5 & $20.0 \pm 0.3$ & $\begin{array}{c}\text { Droplets break liquid } \\
\text { surface and form spherical } \\
\text { beads }\end{array}$ & $3.0 \pm 0.5$ \\
\hline 10 & $60.1 \pm 1.0$ & $\begin{array}{c}\text { Droplets break liquid } \\
\text { surface and form spherical } \\
\text { beads }\end{array}$ & $1.9 \pm 0.19$ \\
\hline 20 & $220.5 \pm 2.5$ & $\begin{array}{c}\text { Droplets get blocked at the } \\
\text { surface }\end{array}$ & N/A \\
\hline 35 & $649.5 \pm 2.5$ & $\begin{array}{l}\text { Droplets get blocked at the } \\
\text { surface }\end{array}$ & N/A \\
\hline
\end{tabular}

The viscosity of the gelatin solution at $22 \mathrm{wt}-\%$ and $60^{\circ} \mathrm{C}$ has been measured and is equal to $133 \mathrm{mPa}$.s. At highest $\mathrm{M}_{\mathrm{w}}$ (i.e 20 and $35 \mathrm{KDa}$ ), the viscosity of PEG solutions is 220.5 and $649.5 \mathrm{mPa}$.s respectively, too high compared to gelatin one for droplets penetration into the polymer solution. They remain blocked at the surface of the bath and it is impossible to recover any beads. $P E G_{5}$ and $P E G_{10}$ are both efficient to form beads but $P E G_{5}$ gives bigger bead diameter. Studies on protein exclusion phenomena by PEG proved that when the degree of PEG polymerization (i.e $\mathrm{M}_{\mathrm{w}}$ ) increases, the mixing entropy is reduced, favoring 
thus the formation of two phases. ${ }^{38}$ So $P E G_{10}$ is chosen as intermediate $M_{w}$ for the rest of the experiments.

Table 3 shows the influence of the gelatin concentration on the beads formation and diameter.

TABLE 3: Influence of the gelatin concentration on the gelatin beads formation; $\left[\mathrm{PEG}_{10}\right]=$ $40 \% \mathrm{w} / \mathrm{v}$.

\begin{tabular}{|c|c|c|c|c|}
\hline $\begin{array}{c}\text { [Gelatin] } \\
\text { (wt-\%) }\end{array}$ & $\begin{array}{l}\text { Gelatin } \\
\text { Density } \rho \\
\left(\mathrm{g} \cdot \mathrm{mL}^{-1}\right)\end{array}$ & $\begin{array}{c}\text { Gelatin } \\
\text { viscosity } \eta \text { at } \\
60^{\circ} \mathrm{C} \text { (mPa.s) }\end{array}$ & $\begin{array}{l}\text { Faisability of beads } \\
\text { formation }\end{array}$ & $\begin{array}{l}\text { Beads diameter } \\
\qquad(\mathrm{mm})\end{array}$ \\
\hline 15 & 1.034 & 39.4 & $\begin{array}{l}\text { Droplets spread out on } \\
\text { the liquid surface }\end{array}$ & N/A \\
\hline 18 & 1.039 & 61.8 & $\begin{array}{l}\text { Droplets spread out on } \\
\text { the liquid surface }\end{array}$ & N/A \\
\hline 20 & 1.045 & 78.2 & $\begin{array}{l}\text { Droplets break liquid } \\
\text { surface and form beads }\end{array}$ & $2.5 \pm 0.48$ \\
\hline 22 & 1.053 & 133 & $\begin{array}{l}\text { Droplets break liquid } \\
\text { surface and form beads }\end{array}$ & $1.9 \pm 0.19$ \\
\hline
\end{tabular}

The formation of the beads is here achieved with a $\mathrm{PEG}_{10}$ solution of $40 \% \mathrm{w} / \mathrm{v}$. The results show that if the concentration of the gelatin solution is less than $20 \mathrm{wt}-\%$, the droplet spread out on the surface, making it impossible to form a bead. The viscosity of $\mathrm{PEG}_{10}$ solution is $60.1 \mathrm{mPa} . \mathrm{s}$ (Table 2) and the droplets penetration is possible when gelatin solution viscosity is 78.2 and $133 \mathrm{mPa} . \mathrm{s}$, suggesting that it needs to be superior to the collecting bath viscosity to form beads by dripping. Another point is to consider that when droplet does not penetrate inside the collecting bath, it is because it has not enough energy to break through the surface. This can be related to the density of the gelatin solution which increases with the concentration rising and thus makes the droplet weight high enough to perforate the 
liquid interface. Additionally, it has also been observed a slight but non significant bead diameter reduction with the increase of gelatin concentration.

A concentration of $22 \mathrm{wt}-\%$ gelatin was therefore chosen, and all the optimized parameters for the beads elaboration are compiled in Table 4.

TABLE 4: Preparation conditions and bead diameter

\begin{tabular}{|c|c|}
\hline [Gelatin] (wt-\%) & 22 \\
\hline PEG $\mathrm{M}_{\mathrm{w}}(\mathrm{KDa})$ & 10 \\
\hline [PEG] (\%w/v) & 40 \\
\hline Temperature of PEG solution $\left({ }^{\circ} \mathrm{C}\right)$ & 50 \\
\hline Syringe pump flowrate $\left(\mathrm{mL} \cdot \mathrm{min}^{-1}\right)$ & 4 \\
\hline Surface tension $\gamma_{\text {gelatin/air }}\left(\mathrm{mN} \cdot \mathrm{m}^{-1}\right)^{*}$ & 40.7 \\
\hline Surface tension $\gamma_{\mathrm{PEG} / \mathrm{air}}\left(\mathrm{mN} \cdot \mathrm{m}^{-1}\right)^{*}$ & $81.7 \pm 2.06$ \\
\hline $\begin{array}{l}\text { Experimental bead diameter } \\
\qquad \Phi_{\text {experimental }}(\mathrm{mm})\end{array}$ & $1.9 \pm 0.19$ \\
\hline $\begin{array}{c}\text { Theoretical bead diameter } \\
\Phi_{\text {theorical }}(\mathrm{mm})^{* *}\end{array}$ & 1.3 \\
\hline
\end{tabular}

* determined by the method described by Worley (1992) based on Tate's Law.

** calculated with the method described by Kamaruddin et al (2014).

Assays are first performed by dripping into a PEG bath with a temperature controlled at $5^{\circ} \mathrm{C}$, with the aim of a fast gelation of the gelatin solution. However, at this low temperature, the droplets remain close to the surface of the bath, while when the temperature is controlled at $50^{\circ} \mathrm{C}$, the beads penetrate deeply in the bath, which ease their formation and improve their sphericity. The bath temperature is therefore fixed at $50^{\circ} \mathrm{C}$ along the dripping process. 
The determination of the gelatin solution density at 22 wt-\% (Table 3 ) and the surface tension of the gelatin/air interface (Table 4) is achieved to use Equation 2 and predict the bead diameter by using the method described by Kamaruddin et al (2014) (see Part 2.6.). A theoretical diameter of $1.3 \mathrm{~mm}$ is found by using a shrinkage factor equal to 1 , thus assuming that the gelatin immersion does not induce any shrinkage of the bead. By comparing this value with the experimental one $(1.9 \pm 0.19 \mathrm{~mm})$, it appears that the gelation does not induce any shrinkage but on the opposite there is a swelling of the polymer matrix which increases the bead size. We can therefore make the assumption that this theoretical diameter corresponds rather to the bead size before immersion in the PEG solution. A simple calculation of the ratio of the bead volumes after and before gelation, (considering that the bead volume is $V=\pi \cdot d_{p}^{3} / 6$ ) shows that the bead volume of gelatin is three times more important after gelation (with $d_{p}=1.9 \mathrm{mmm}$ ) in the PEG solution compared to the bead volume after detachment from the tip (with $d_{p}=1.3 \mathrm{~mm}$ ). The bead volume before gelation is dependent of the gelatin/air surface tension and the tip diameter. The tip diameter was determined to be $0.54 \mathrm{~mm}$, which is already relatively low, regarding the flowing of the relatively viscous gelatin solution. According to the predictive model and our experimental observations, it can be concluded that the production of gelatin beads using our experimental set-up can only lead to beads with diameter close to $2 \mathrm{~mm}$. The swelling of the gelatin spheres associated to the viscosity of the protein solution make impossible the production of beads with smaller diameter. A reduction of a tip diameter would be necessary but implies also the use of higher pressure to pump the gelatin solution.

The surface tensions of PEG/air and gelatin/air interfaces are calculated by using Tate's law (Table 4). It can be noted that the surface tension of PEG/air interface is twice higher than the one of gelatin/air. Gelatin droplets need to break the PEG/air interface to penetrate into 
the PEG solution. This can be related to the minimal density $\left(1.045 \mathrm{~g} \cdot \mathrm{mL}^{-1}\right)$ required for the gelatin solution to penetrate the PEG solution (see Table 3).

\section{FTIR analysis}

A typical FTIR spectrum of un-crosslinked gelatin hydrogel ( $22 \mathrm{wt}-\%)$ is presented in Figure 3. It displays the characteristics bands of gelatin: the large band around $3300 \mathrm{~cm}^{-1}$ corresponds to the amide- $\mathrm{A}$ peak $(\mathrm{N}-\mathrm{H}$ stretching band) as well as free water; the amide $\mathrm{I}(\mathrm{C}=\mathrm{O})$ is detected from the peak around $1630 \mathrm{~cm}^{-1}$, the amide II (N-H and C-H bands) is represented by the peak around $1550 \mathrm{~cm}^{-1}$, and the small peaks at around $1240 \mathrm{~cm}^{-1}$ matches the amide III bonds $(\mathrm{C}-\mathrm{N}, \mathrm{N}-\mathrm{H}) .^{39,40}$

No others bands are present in the spectrum, thus it can be concluded that the polyethylene glycol is correctly washed and do not affect the chemical composition of gelatin beads. It confirms that PEG molecules are not inserted in the gelatin beads. Their use is needed to hinder gelatin mixing in the coagulation bath and thus allows maintaining the bead shape of the droplets. 


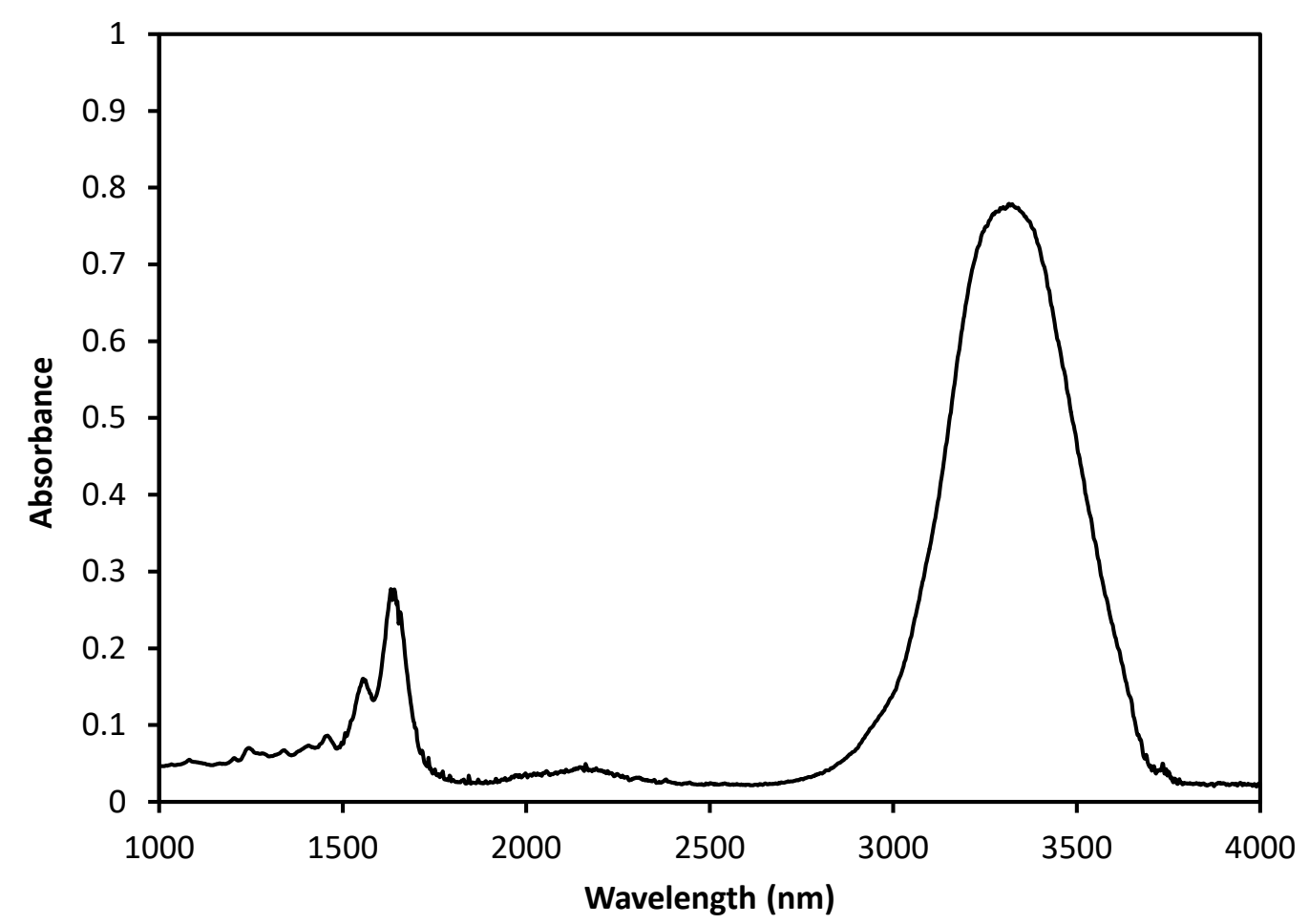

FIGURE 3: FT-IR spectrum of uncross-linked gelatin hydrogel

\section{Influence of the cross linking ratio on the gelatin beads properties}

The cross linking ratio of gelatin beads has been studied in order to maximize the number of active sites where the enzymes can be grafted as well as to improve the mechanical properties of the beads. Gelatin is indeed a material which has the ability to absorb a high quantity of water, and this property can become a problem for the use in aqueous media.

Due to the multiplicity of GTA forms in aqueous solution, it is quite difficult to have a simple explanation for the crosslinking mechanism, as several reactions probably happen at the same time. The most commonly accepted hypothesis in the literature is the reaction between aldehyde groups of GTA with the lysine residues of gelatin to form a Schiff base. More specifically, the amino groups $\left(-\mathrm{NH}_{2}\right)$ of lysin residues proceed in a nucleophile 
reaction with the carbonyl group $(\mathrm{C}=\mathrm{O})$ of GTA. The probable mechanism of this reaction is given in figure 4.

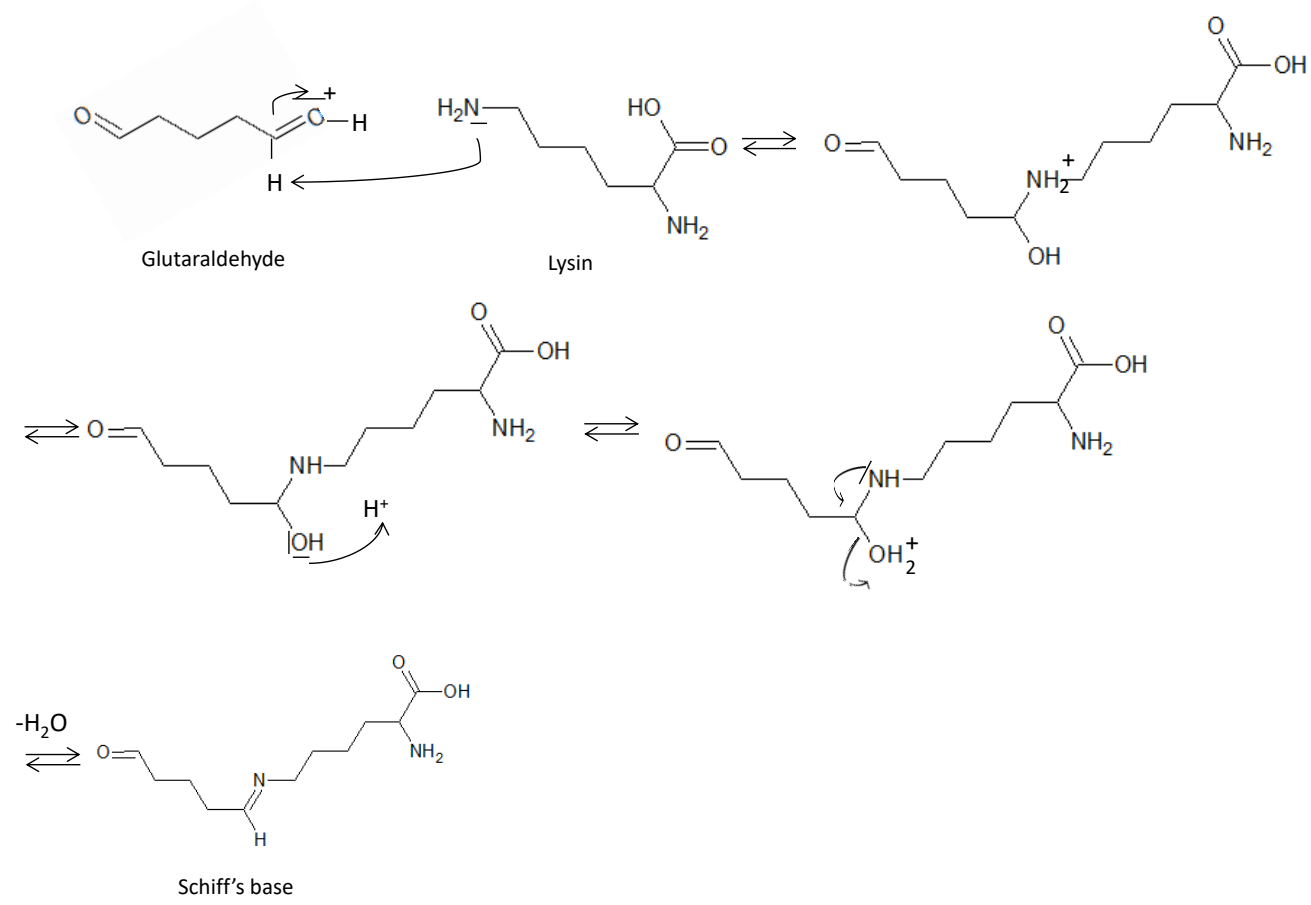

FIGURE 4: Nucleophile reaction between lysin residue of gelatin and carbonyl groups of glutaraldehyde

Moreover, GTA molecules will undergo a polymerization by aldol condensation, and the imine linkages of the Schiff base formed will thus be stabilized by conjugation. ${ }^{41}$ It has been currently reported in the literature that the reaction of GTA and proteins can be monitored by a color modification from white to yellow-orange. This change had been explained by the conjugation of the double bonds which generate light absorption. ${ }^{42}$ Gelatin cylindrical hydrogels are cross-linked (from 0\% GTA to 3\% GTA). Figure 5 displays the enhancement of the color intensity of gelatin cylinders together with the GTA concentration. This result indicates the increase of the imine linkages of the Schiff base formed between aldehyde groups of GTA molecules with the lysine residues of gelatin as explained above. ${ }^{43}$ 
Beside these qualitative observations, TNBS assay ${ }^{34}$ is used to determined quantitatively the final crosslinking ratio of the gelatin beads in relation with the concentration of GTA used during the crosslinking step (Figure 6). It can be observed that when the GTA concentration increases, the cross linking ratio increases very rapidly up to $100 \%$ for a $2 \%$ of GTA concentration, with small deviation around $100 \%$. Then from $3 \%$ no deviation around $100 \%$ was observed.

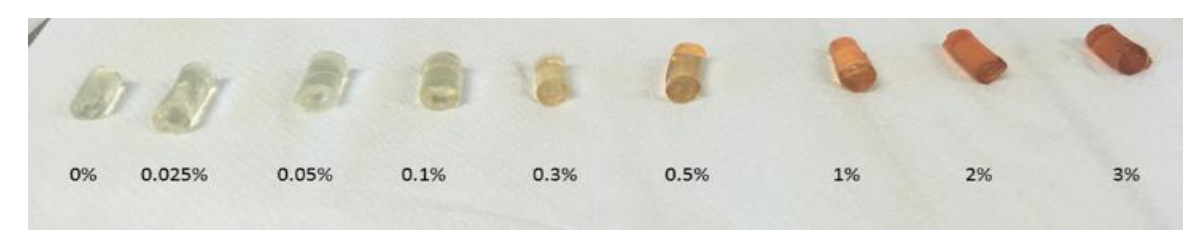

FIGURE 5: Evolution of the color of the gelatin gels with the crosslinking ratio (left to right:

0\% GTA to $3 \%$ GTA) 


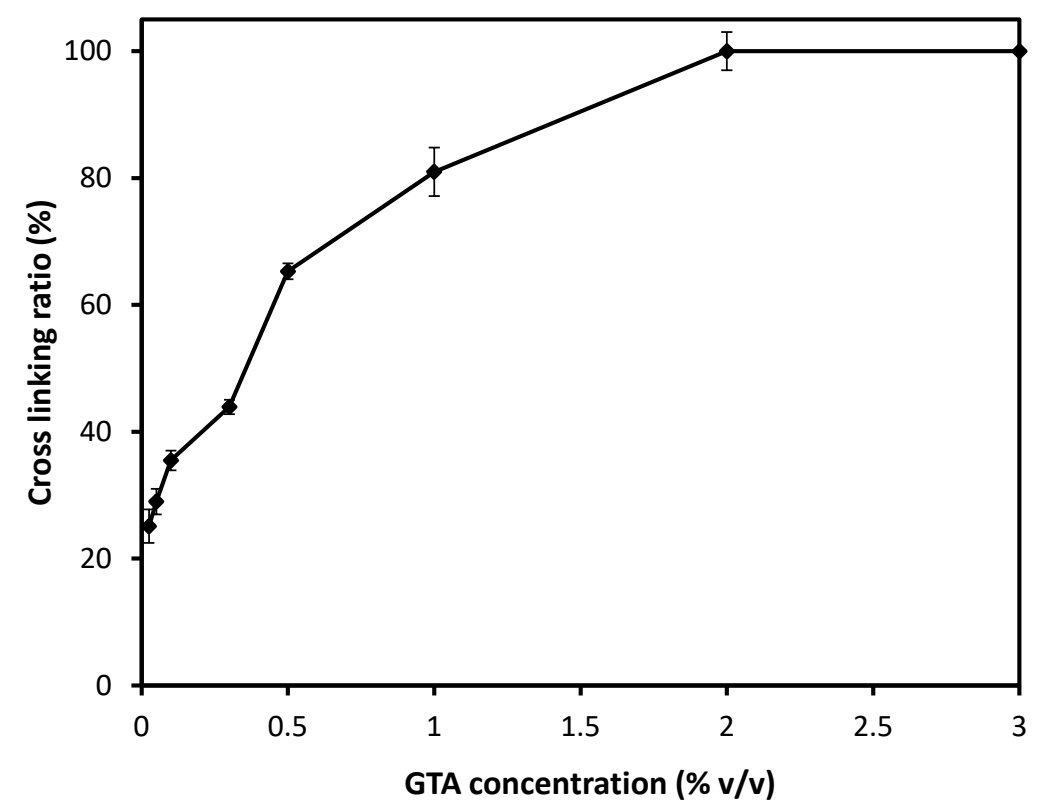

FIGURE 6: Evolution of the gelatin beads cross-linking ratio versus the glutaraldehyde concentration used during cross-linking

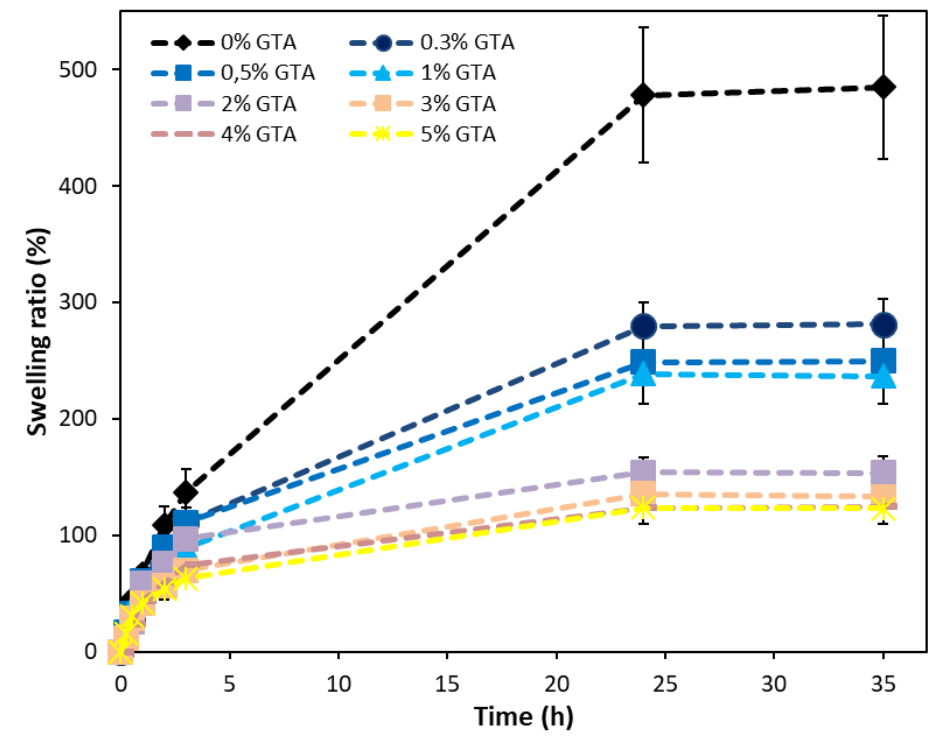

FIGURE 7: Impact of the glutaraldehyde cross-linking on the gelatin gels swelling ratio 
With the aim to confirm the results obtained with TNBS assay, cross-linked gels have been immersed in water for $35 \mathrm{~h}$ and the swelling ratio is determined with time up to $35 \mathrm{~h}$ (Figure 7). The gelatin beads present a much lower swelling ability once cross linked. After 24 hours of immersion in water, the beads without cross linking have an important swelling ratio (485\%), whereas when cross linked with a GTA solution of $3 \%$, the swelling ratio is reduced to $135 \%$. No significant difference on the swelling ratio between GTA concentrations of $3 \%$, $4 \%$ or $5 \%$ is observed which confirms the results obtained with TNBS assay (Figure 6): from $3 \%$ GTA, it can be considered that the cross-linking reaction between GTA and gelatin is completed.

Previous studies confirm the result that cross linking reduces the capability of a gel to absorb water. $^{44,45}$ This property can be explained by the reaction of the GTA with the amine functions of gelatin, which prevents them to interact and form hydrophilic bonds with water molecules, and which reduces the chain mobility.

The mechanical properties of the as-prepared gel are then determined, first on the gels themselves then on the gels after $24 \mathrm{~h}$ immersion in water and using the immersion mode of the instrument. The Young modulus, stress at break, and strain at break of gelatin hydrogels cross linked with different amount of GTA are given in Table 5. 
TABLE 5: Comparison of gelatin hydrogels mechanical properties before and after 24 hours immersion

\begin{tabular}{|c|c|c|c|c|c|c|}
\hline \multirow{2}{*}{$\begin{array}{r}{[\text { GTA }]} \\
(\%)\end{array}$} & \multicolumn{2}{|c|}{ Young modulus (MPa) } & \multicolumn{2}{|c|}{ Stress at break (kPa) } & \multicolumn{2}{|c|}{ Strain at break (\%) } \\
\hline & $\begin{array}{c}\text { Before } \\
\text { immersion }\end{array}$ & $\begin{array}{l}\text { After } 24 \mathrm{~h} \\
\text { immersion }\end{array}$ & Before immersion & $\begin{array}{l}\text { After } 24 \mathrm{~h} \\
\text { immersion }\end{array}$ & $\begin{array}{c}\text { Before } \\
\text { immersion }\end{array}$ & $\begin{array}{l}\text { After } 24 \mathrm{~h} \\
\text { immersion }\end{array}$ \\
\hline 0 & $0.8 \pm 0.05$ & $0.7 \pm 0.06$ & $36.3 \pm 1.25$ & $20.0 \pm 1$ & $10.3 \pm 0.5$ & $9.0 \pm 0.5$ \\
\hline 0.5 & $1.27 \pm 0.06$ & $1.09 \pm 0.26$ & $55.3 \pm 3.8$ & $40 \pm 16.3$ & $10.6 \pm 0.5$ & $9.0 \pm 0.9$ \\
\hline 1 & $1.32 \pm 0.11$ & $1.59 \pm 0.10$ & $66.7 \pm 2.4$ & $73.3 \pm 4.7$ & $11.0 \pm 0.2$ & $11.00 \pm 0.01$ \\
\hline 2 & $1.62 \pm 0.13$ & $1.84 \pm 0.16$ & $96 \pm 12$ & $156.7 \pm 4.7$ & $11.7 \pm 0.5$ & $12.0 \pm 0.5$ \\
\hline 3 & $2.30 \pm 0.24$ & $2.01 \pm 0.01$ & $227.5 \pm 6.0$ & $\begin{array}{c}133.3 \pm \\
57.0\end{array}$ & $12.0 \pm 0.1$ & $10.0 \pm 0.9$ \\
\hline 4 & $2.13 \pm 0.08$ & $2.32 \pm 0.22$ & $223.3 \pm 20$ & $\begin{array}{c}223.3 \pm \\
57.0\end{array}$ & $13.7 \pm 0.5$ & $12.0 \pm 1.2$ \\
\hline 5 & $1.92 \pm 0.30$ & $1.90 \pm 0.19$ & $180 \pm 43$ & $183 \pm 15$ & $12.0 \pm 0.9$ & $11.0 \pm 0.9$ \\
\hline
\end{tabular}

The data clearly show that initially, the Young modulus of un-crossliked gelatin is relatively low (0.8 MPa). When the cross linking degree is increased, the Young modulus for gels with and without immersion increases until a plateau reached from 3\% GTA (Young modulus 2.1 $\mathrm{MPa}$ ), even if from $5 \%$ it seems to decrease but results are not really significant. Concerning stress and strain at break, a similar phenomenon is observed. It can be explained by the fact that when the cross linking degree increases, the number of covalent bonds in the gelatin structure increases as well, which strengthen the gel. TNBS assay demonstrated that from 3\% GTA the cross-linking ratio was maximum (Figure 5). Bigi (2001) and Talebian 
(2007) have previously shown that Young modulus and stress at break of gelatin increase with the $\%$ of GTA and thus the degree of cross-linking. ${ }^{36,46}$ Amounts of GTA higher than 3\% do not improve the mechanical properties of the gel.

As the main application for these gelatin beads is to be used as enzyme immobilization supports in permanent contact with water, it is relevant to consider rather the mechanical properties of the gels after 24 hours of immersion in water. However results do not display significant change and here again the value of 3\% GTA seems suit for cross-linking. It can also be concluded that the stiffness of the gelatin beads is increased by GTA cross-linking, allowing a sustainable use in aqueous solutions.

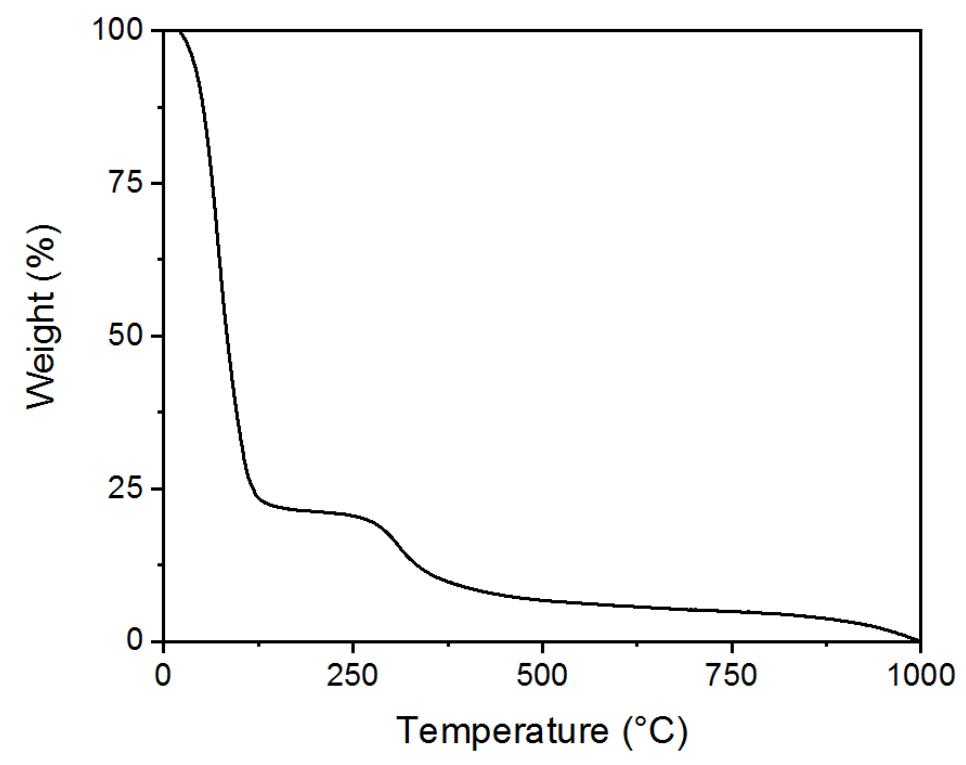

FIGURE 8: Typical TGA curve of a gelatin sample (22 wt-\%)

The thermal stability of the gels was also evaluated because gelatin is well-known to display a gelation temperature close to ambient conditions. Firstly, it has been observed that the beads resist to immersion in water up to $100^{\circ} \mathrm{C}$ once cross-linked with $3 \%$ GTA. Figure 8 
represents a typical thermographic analysis (TGA) curve of uncross-linked gelatin gel (22 wt$\%)$. The first part of the curve coincides with the water evaporation, around $100^{\circ} \mathrm{C}$, and the second decrease matches with gelatin degradation, starting at around $200^{\circ} \mathrm{C}$. According to the TGA results; the temperature range $-40^{\circ} \mathrm{C}$ to $200^{\circ} \mathrm{C}$ was selected for the DSC experiments, at a rate of $20^{\circ} \mathrm{C} / \mathrm{min}$.

DSC scans allow the determination of the triple helix denaturation temperature $T_{d}$ of gelatin gels. Figure 9 displays the thermograph of uncross-linked gelatin (curve labelled nr), and of gelatin gel cross-linked with $1 \%$ GTA. The endothermic peak around $100^{\circ} \mathrm{C}$ for the uncross-linked sample and around $150^{\circ} \mathrm{C}$ for the cross-linked one matches to melting point, that is to say the denaturation of the triple helix into a random configuration, with rupture of hydrogen bond. The thermal transition $T_{g}$ is quite difficult to see here, probably hidden with the melting peak for the black curve, but it can be guessed around $100^{\circ} \mathrm{C}$ for the crosslinked gel. This experiment has been made for different samples, not displayed in the same figure, but all the results are shown in Table 6 . 


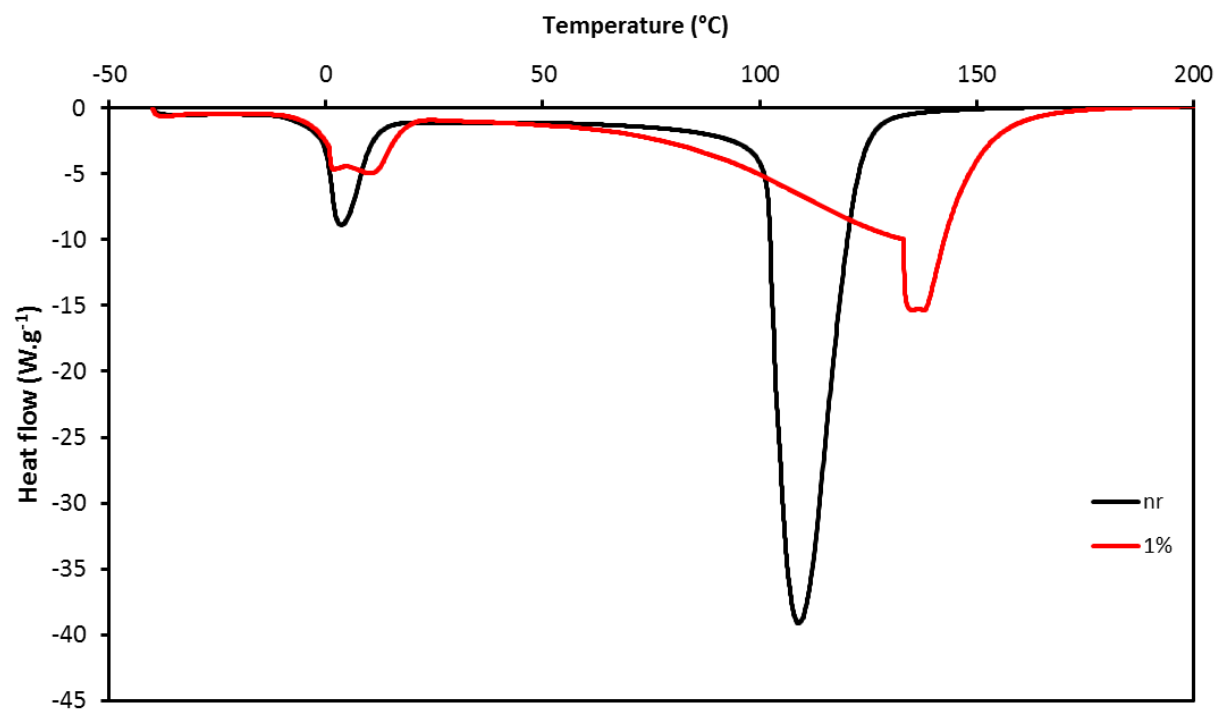

FIGURE 9: DSC thermographs of gelatin un-crosslinked (nr) and cross-linked with 1\% GTA

It can be observed a simultaneous enhancement of the cross-linking and the melting temperature $\left(T_{d}\right)$, while the corresponding enthalpy $(\Delta H)$ decreases. This behavior can be explained by the fact that when cross-linked, the number of covalent links between gelatin and GTA molecules increase. Thus, the stability of the structure is improved and the triple helix denaturation temperature increases. And as the hydrogen bonds break endothermically while covalent bonds break exothermically, the denaturation enthalpy is decreasing because of the decrease of the number of hydrogen bonds and the increase of the number of covalent bonds. ${ }^{47,48}$ 
TABLE 6: Thermal properties of gelatin hydrogels

\begin{tabular}{c|cc}
\hline GTA $(\% \mathrm{v} / \mathrm{v})$ & $\mathrm{T}_{\mathrm{d}}\left({ }^{\circ} \mathrm{C}\right)$ & $\Delta \mathrm{H}(\mathrm{J} / \mathrm{g})$ \\
\hline 0 & $110 \pm 4$ & $21 \pm 4$ \\
\hline 0.5 & $123 \pm 5$ & $11 \pm 3$ \\
\hline 1 & $133 \pm 5$ & $10 \pm 4$ \\
\hline 3 & $133 \pm 6$ & $7 \pm 2$ \\
\hline 5 & $136 \pm 2$ & $6 \pm 1$ \\
\hline
\end{tabular}

All these characterizations provide evidences of gelatin beads cross-linking and allowed us to select a concentration of GTA of $3 \% \mathrm{v} / \mathrm{v}$ for the rest of the experiments. These conditions allow the preparation of gelatin beads displaying enough stability for further use in aqueous solutions.

\section{Enzymatic activity, stability, and reusability}

Gelatin beads are a support of choice for enzyme immobilization because gelatin displays numerous available amino functional groups, which can react with free aldehyde functions of glutaraldehyde without supplementary functionalization, and lead to robust covalent bonds. Secondly, this biopolymer is relatively cheap and widely produced at industrial scale. Moreover, gelatin is a bio-based polymer so biodegradation can be envisioned when enzymes become inactive. The immobilization of laccase from Trametes versicolor is carried out as explained in the experimental section, on gelatin beads of $2 \mathrm{~mm}$ of diameter and cross-linked with $3 \%$ of GTA solution.

The enzymatic activity is measured with ABTS. After immobilization, the beads show an activity of $0.1 \mathrm{U} \cdot \mathrm{g}^{-1}$. The enzyme loading amount could not be directly determined because 
of the proteic nature of both the enzymes and the support. However the immobilization yield (equations 4 and 5) was found to be $31 \pm 6 \%$ and the expressed activity (equation 6 ) is $50 \pm 5 \%$. The immobilization yield and the expressed activity are thus inferior to $100 \%$, meaning that grafting conditions may be improved to increase these parameters.

As immobilization can modify the $\mathrm{pH}$ and temperature profiles of laccase, the effect of $\mathrm{pH}$ and temperature on both free and immobilized laccase activities has been studied, within a range of $\mathrm{pH}$ from 2.2 to 6 and a range of temperature from 20 to $55^{\circ} \mathrm{C}$.
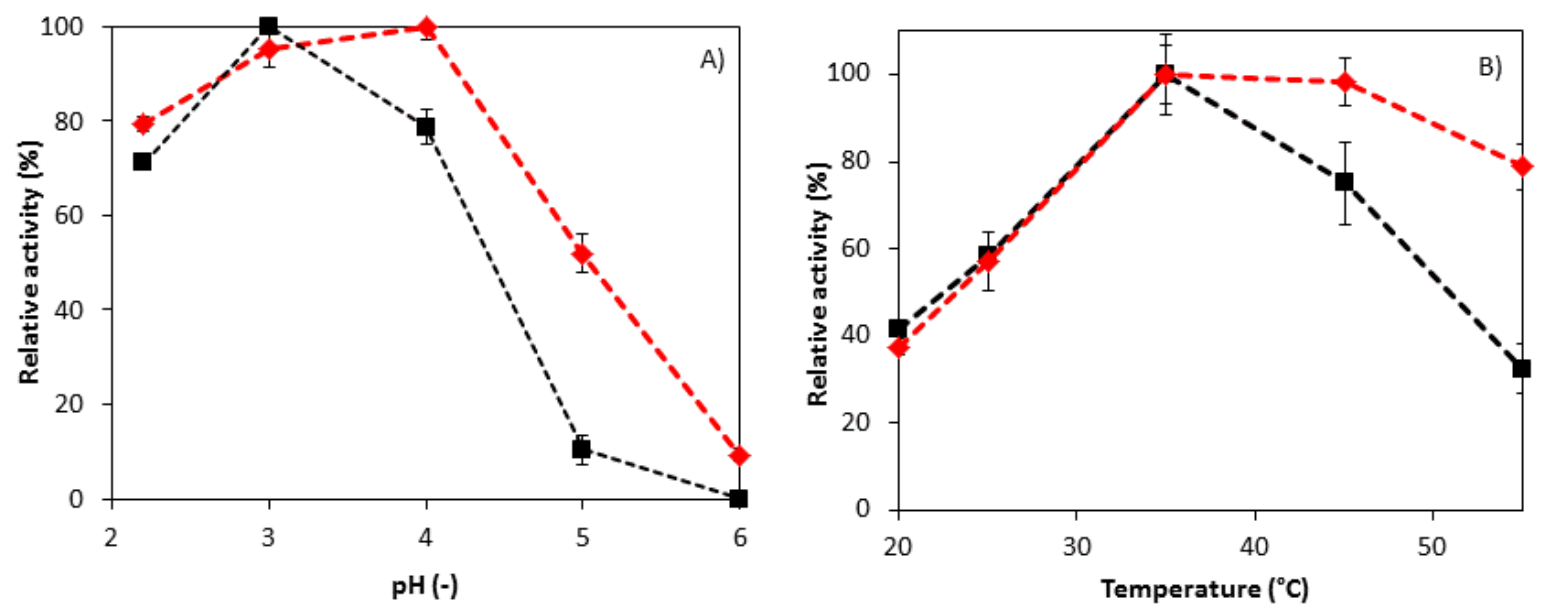

FIGURE 10: A) pH profiles for free (black curve) and immobilized (red curve) enzymes, at 25 ${ }^{\circ} \mathrm{C}$ and $\mathrm{B}$ ) Temperature profiles for free (black curve) and immobilized (red curve) enzymes, at $\mathrm{pH} 4$.

The figure 10.A) represents the $\mathrm{pH}$ profiles for free and immobilized laccase towards ABTS oxidation. The optimum $\mathrm{pH}$ values were 3 and 4 , respectively for free and immobilized laccases. The shift of value could be explained by modifications in enzyme conformation and ions partitioning due to binding to the supports. ${ }^{49}$ At higher $\mathrm{pH}$, the relative activity decreases strongly for both free and immobilized enzymes. At $\mathrm{pH} 5$, for free enzymes, the relative activity has already decreased until $10 \% \pm 3 \%$, and no activity is observed at $\mathrm{pH} 6$. For immobilized enzymes, $52 \% \pm 4 \%$ of relative activity remains at $\mathrm{pH} 5$ and there is still $10 \%$ $\pm 2 \%$ relative activity at $\mathrm{pH} 6$. The immobilized laccase thus shows higher resistance to $\mathrm{pH}$ 
changes in the medium, and similar conclusions can be found in literature with various supports. ${ }^{13,50}$ The rest of the experiments will be performed at $\mathrm{pH} 4$ as it is the optimized value for immobilized enzymes.

The figure 10.B) shows that the temperature profiles of both free and immobilized laccases follow a similar pattern, as their activity increase from 20 to $35^{\circ} \mathrm{C}$, reach an optimum at $35^{\circ} \mathrm{C}$ and decrease until $55^{\circ} \mathrm{C}$. The activity of free enzymes decreases to $75 \% \pm 9 \%$ of relative activity at $45^{\circ} \mathrm{C}$ and $32 \% \pm 5 \%$ relative activity at $55^{\circ} \mathrm{C}$. The decrease of immobilized enzymes is less drastic and retains $98 \% \pm 5 \%$ activity at $45^{\circ} \mathrm{C}$ and $79 \% \pm 4 \%$ at $55^{\circ} \mathrm{C}$. Immobilization seems to prevent enzymes from structural transformation when confronted to higher temperatures, several studies have already observed this result with diverse immobilization supports. $^{51-53}$

The kinetics parameters of Michaelis-Menten $\mathrm{K}_{\mathrm{m}}$ and $\mathrm{V}_{\max }$ can characterize the biocatalyst activity towards a chosen substrate. Here, the affinity of free and immobilized laccase onto gelatin beads towards ABTS are compared.

The results obtained with Lineweaver-Burk equation are represented in Table 7 . The affinity of an enzyme towards a given substrate is higher when $\mathrm{K}_{\mathrm{m}}$ is low whereas the reactivity increases with $V_{\max }$ enhancement. Results show that in the case of $A B T S$, the $K_{m}$ is lower when laccase is immobilized onto gelatin beads when compared with free enzymes, while $V_{\max }$ is slightly higher with immobilized enzymes than with free enzymes. It is important to note that the value of $V_{\max }$ depends on the enzymes concentration and can only be compared if the amounts of enzymes used are identical for both enzyme forms. In our case the experiments are carried out at the same enzyme "activity" (30 U.L $\left.{ }^{-1}\right)$ for the both forms of laccases; it is therefore not surprising that the $V_{\max }$ values are close. It is thus not possible 
to conclude whether or not immobilization on gelatin beads improves the reactivity of the laccase of Trametes versicolor. Commonly in the literature is reported that immobilization on inorganic or polymer supports causes diffusional limitations and decreases protein flexibility and then gives a more difficult approach of the substrate to active sites of the enzyme. ${ }^{54-56}$ However, some studies have noticed a decrease of $\mathrm{K}_{\mathrm{m}}$ when laccase from Trametes Versicolor is immobilized on gelatin supports. Asgher M. et al (2017) reported a slight decrease of $K_{m}$ in gelatin entrapped laccase compared to free laccase. ${ }^{57}$ De Cazes M. et al (2014) reported a value of $K_{m} 5$ times lower than free laccase when laccase was covalently immobilized on ceramic membranes coated by a glutaraldehyde crosslinked gelatin layer. ${ }^{58}$ Thus, the present results confirm that gelatin seems to have a positive effect probably with less diffusional hindrance than traditional inorganic or polymer supports.

TABLE 7: Kinetics constants of laccase towards ABTS

\begin{tabular}{c|cc}
\hline & $\begin{array}{c}\mathrm{V}_{\max } \\
\left(\mu \mathrm{mol} \cdot \mathrm{min}^{-1}\right)\end{array}$ & $\mathrm{K}_{\mathrm{m}}\left(\mu \mathrm{mol} . \mathrm{L}^{-1}\right)$ \\
\hline Free enzymes & $0.029 \pm 0.001$ & $55.6 \pm 0.73$ \\
\hline $\begin{array}{c}\text { Immobilized } \\
\text { enzymes }\end{array}$ & $0.033 \pm 0.005$ & $38.0 \pm 2.6$ \\
\hline
\end{tabular}

One of the advantages of enzyme immobilization is that enzymes can be recovered and reused instead of having to be separated at the end of every reaction cycle. To verify this possibility, ten successive reactions have been carried out with the same beads. At the end of each cycle, the reaction medium is poured; beads are rinsed with water and added to a fresh ABTS solution. Figure 11 shows the relative activity of the immobilized enzyme for each cycle. It can be noticed that the activity globally decreases as the number of cycles increases, especially in the two first cycles, in which an abrupt decrease from 100 to $60 \%$ was 
observed. This decrease of activity would be caused by protein leakage from the beads or enzyme conformational changes leading to denaturation..$^{59,60}$ Indeed, it can be assumed that a part of enzymes are physically adsorbed onto the gelatin chains by weak interactions and are then released in the medium along the two first cycles, explaining why after the activity is roughly constant between cycle 3 and 10 . However, the activity is then maintained at $60 \%$ until the end of the $10^{\text {th }}$ cycle, which proves the presence of covalent bonds between laccase and gelatin and the ability of gelatin beads to become efficient enzyme supports.

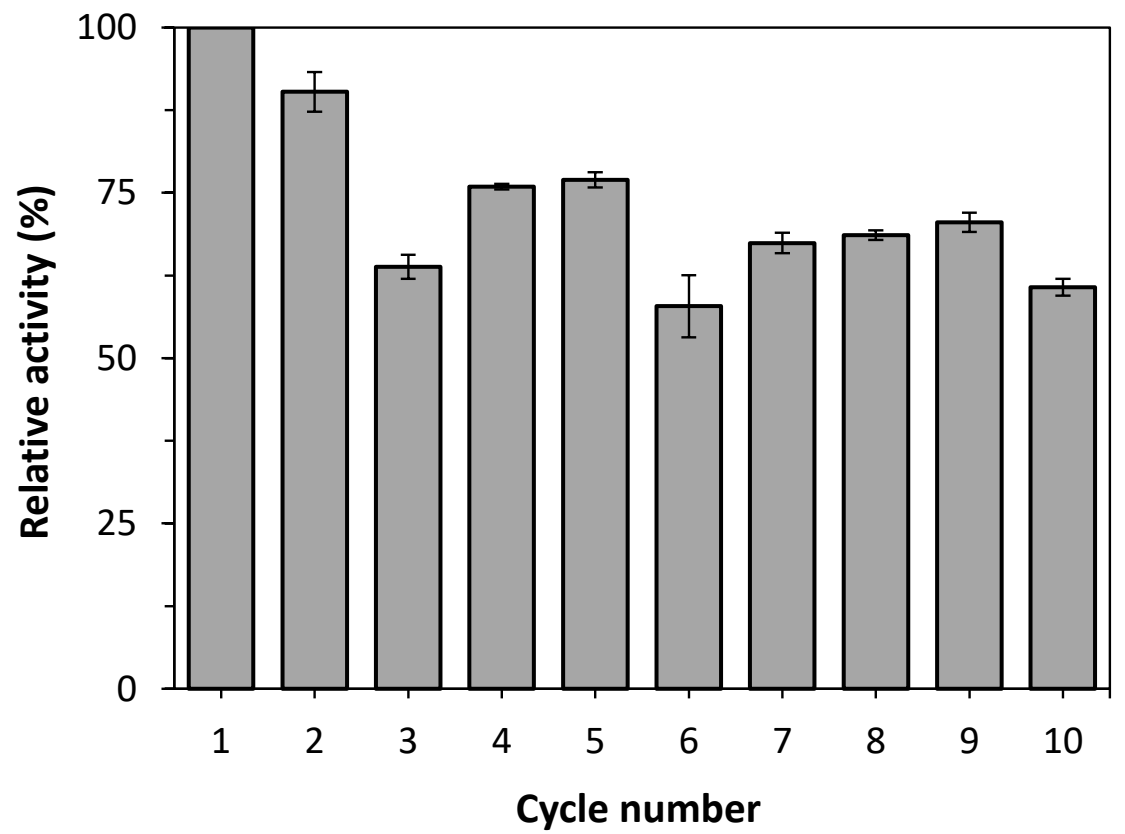

FIGURE 11: Relative activity of immobilized enzymes after several cycles of reactions with ABTS

To evaluate the ability of immobilization to enhance enzyme stability, free and immobilized laccase are incubated for 6 hours at $60^{\circ} \mathrm{C}$ and their activity is measured every hour (Figure 12). It is observed that high temperature affects negatively the activity of enzymes. This result is well-known and can be explained because of the conformational change due to temperature increase. ${ }^{61}$ Free enzymes activity decreases indeed to $40 \%$ after 1 h30 of 
incubation and less than $10 \%$ after 6 hours. With the immobilized enzymes, the activity decreases as well but the effect of temperature is less drastic and activity remains at a correct level ( $45 \%$ of relative activity after 6 hours at $60^{\circ} \mathrm{C}$ ). The immobilization has a stabilizing effect on the enzyme, preventing molecular mobility and deformation of the active site. Other studies have shown similar results with different enzymes supports. ${ }^{51,62}$

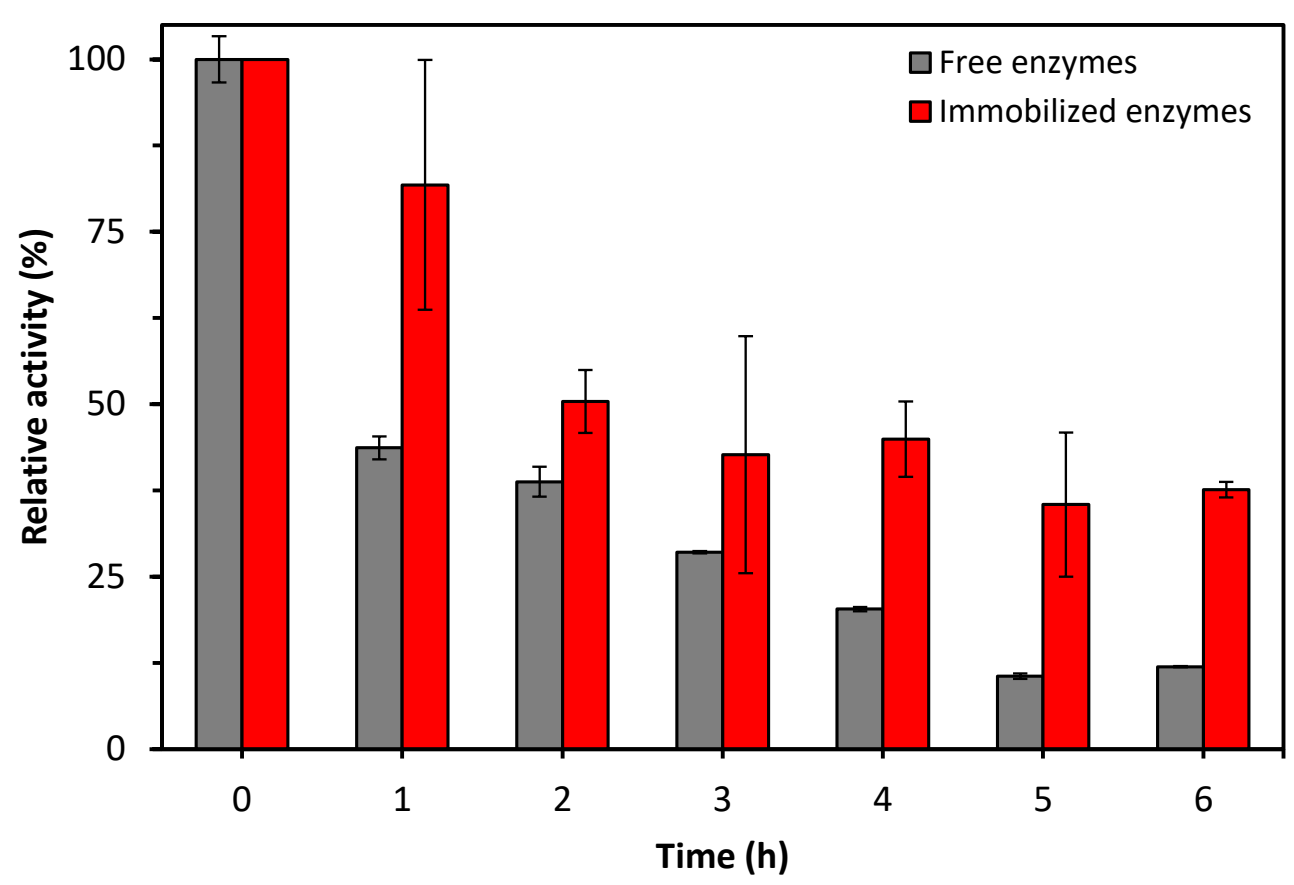

FIGURE 12: Stability of free or immobilized enzyme towards temperature

\section{CONCLUSIONS}

A novel preparation method is established to form biocatalysts consisting of laccases immobilization on gelatin millimeter size beads. The gelatin supports are prepared by dripping a gelatin solution (22 wt-\%) inside a collecting bath of $\mathrm{PEG}_{10}$ solution (40 wt-\%) at $50^{\circ} \mathrm{C}$. Theoretical calculations, validated by experimental results, demonstrated that the 
bead diameters are dependent on the tip diameter, the gelatin solution viscosity and is affected by the gelatin swelling in the collecting bath. A cross-linking step with glutaraldehyde allows to improve the mechanical and thermal properties of the beads, but also to covalently bond laccases on the surface of the beads. The optimum \% of GTA in the aqueous cross-linking bath is $3 \%$. The active bio based beads display a good reusability during several reaction cycles, and the stability of the enzymes at $60^{\circ} \mathrm{C}$ increases with immobilization. The kinetics constants have also shown that the immobilization increased the affinity between the enzymes and a specific substrate, ABTS. The gelatin beads are thus a promising laccase immobilization supports for micro pollutants degradation in aqueous solution, even at $60^{\circ} \mathrm{C}$. These innovative sustainable biocatalysts have been developed to be used as catalytic bed in a fluidized bed reactor for the bioremediation of micro pollutants in water. Indeed, laccase can oxidize a broad range of recalcitrant micro pollutants into less toxic products. From an environmental point of view, this method uses actually only glutaraldehyde as hazardous chemicals but it is used in diluted solutions (3\% v/v) and unreacted GTA can be recycled for further use. Otherwise, gelatin and laccase are naturally occurring compounds and the collection bath is composed of a non toxic PEG solution.

\section{ACKNOWLEDGMENTS}

The author would like to convey thanks to the Ministry for granting the thesis scholarship to pursue this research. This work was supported by the "Institut Européen des Membranes" through the water project (ENZYCLEAN).

\section{REFERENCES}


1. V. Ferreira-Leitão, M. Cammarota, E. Gonçalves Aguieiras, L. Vasconcelos de Sá, R. FernandezLafuente, D. Freire, Catalysts 2017, 7, 9.

2. R.A. Sheldon, J.M. Woodley, Chem. Rev. 2018, 118, 801-838.

3. H. Sun, H. Zhang, E.L. Ang, H. Zhao, Bioorg. Med. Chem. 2018, 26, 1275-1284.

4. G.W. Huisman, S.J. Collier, Curr. Opin. Chem. Biol. 2013, 17, 284-292.

5. M. Bilal, H.M.N. Iqbal, Food Res. Int. 2019, 123, 226-240.

6. A.K. Patel, R.R. Singhania, A. Pandey, Curr. Opi. Food Sci. 2016, 7, 64-72.

7. M.B. Ansorge-Schumacher, O. Thum, Chem. Soc. Rev. 2013, 42, 6475.

8. F. Shakerian, J. Zhao, S.-P. Li, Chemosphere 2020, 239, 124716.

9. L.Y. Jun, L.S. Yon, N.M. Mubarak, C.H. Bing, S. Pan, M.K. Danquah, E.C. Abdullah, M. Khalid, J. Environ. Chem. Eng. 2019, 7, 102961.

10. A. Basso, S. Serban, Mol. Catal. 2019, 479, 110607.

11. J. Zdarta, A.S. Meyer, T. Jesionowski, M. Pinelo, Ad. Colloid Interface Sci. 2018, 258, 1-20.

12. A. Sola-Rabada, P. Sahare, G.J. Hickman, M. Vasquez, L.T. Canham, C.C. Perry, V. Agarwal, Colloids and Surf., B. 2018, 166, 195-202.

13. J. Hou, G. Dong, Y. Ye, V. Chen, J. Membr. Sci. 2014, 452, 229-240.

14. C. Chao, J. Liu, J. Wang, Y. Zhang, B. Zhang, Y. Zhang, X. Xiang, R. Chen, ACS Appl. Mater. Interfaces 2013, 5, 10559-10564.

15. M. Bilal, H.M.N. Iqbal, Int. J. Biol. Macromol. 2019, 130, 462-482.

16. T. Doğan, E. Bayram, L. Uzun, S. Şenel, A. Denizli, J. Appl. Polym. Sci. 2015, 132, 41981.

17. C. Altinkaynak, S. Tavlasoglu, N. ÿzdemir, I. Ocsoy, Enzyme and Microb. Technol. 2016, 93-94, 105-112.

18. D. Wang, W. Jiang, Int. J. Biol. Macromol. 2019, 126, 1125-1132.

19. S. Kumar, I. Haq, J. Prakash, A. Raj, Int. J. Biol. Macromol. 2017, 98, 24-33.

20. J. Li, J. Ma, Y. Jiang, T. Jiang, Y. Wang, Y. Chen, S. Liu, J. Mater. Sci. 2016, 51, 6357-6369.

21. M. Bilal, M. Asgher, H.M.N. Iqbal, H. Hu, X. Zhang, Catal. Lett. 2016, 146, 2221-2228. 
22. R. Schrieber, H. Gareis, Gelatine Handbook: Theory and Industrial Practice, Wiley-VCH-Verl, Weinheim 2007.

23 O. Franssen, W.E. Hennink, Int. J. Pharm. 1998, 168, 1-7.

24. J. Gómez-Estaca, R. Gavara, P. Hernández-Muñoz, Innov. Food Sci. Emerg. Technol. 2015, 29, 302.

25. M.L. Bruschi, M.L.C. Cardoso, M.B. Lucchesi, M.P.D. Gremião, Int. J. Pharm. 2003, 264, 45-55.

26. M.A. Vandelli, F. Rivasi, P. Guerra, F. Forni, R. Arletti, Int. J. Pharm. 2001, 215, 175-184.

27. R. Cortesi, E. Esposito, M. Osti, E. Menegatti, G. Squarzoni, S.S. Davis, C. Nastruzzi, Eur. J. Pharm. Biopharm. 1999, 47, 153-160.

28. Y. Kong, D. Li, L. Wang, B. Adhikari, J. Food Eng. 2011, 103, 9-13.

29. M.A. Kamaruddin, M.S. Yusoff, H.A. Aziz, Int. J. Technol. 2014, 5, 121-132.

30. F. Davarcı, D. Turan, B. Ozcelik, D. Poncelet, Food Hydrocolloids. 2017, 62, 119-127.

31. J.M. Lee, E.-S. Chan, R. Nagasundara Ramanan, C.W. Ooi, Fluid Phase Equilibr. 2020, 508, 112441.

32. B. Varga, V. Somogyi, M. Meiczinger, N. Kováts, E. Domokos, J. Cleaner Prod. 2019, 221, 306322.

33. C. Barrios-Estrada, M. de Jesús Rostro-Alanis, B.D. Muñoz-Gutiérrez, H.M.N. Iqbal, S. Kannan, R. Parra-Saldívar, Sci. Total Environ. 2018, 612, 1516-1531.

34. J. Worley, Journal of Chemical Education 1992, 69, 678-680.

35. C.M. Ofner, W.A. Bubnis, Pharm. Res. 1996, 13, 1821-1827.

36. A. Bigi, G. Cojazzi, S. Panzavolta, K. Rubini, N. Roveri, Biomaterials. 2001, 22, 763-768.

37. R. Bhat, S.N. Timasheff, Protein Sci. 1992, 1, 1133-1143.

38. J.M. Harris, Poly(Ethylene Glycol) Chemistry: Biotechnical and Biomedical Applications, 1992.

39. C. Tengroth, U. Gasslander, F. Andersson, S. Jacobsson, Pharm. Dev. Technol. 2005, 10, 405-412.

40. Y. You, X. Sun, Q. Cui, B. Wang, J. Ma, BioResources. 2016, 11, 6162-6173.

41. P. Monsan, G. Puzo, H. Mazarguil, Biochimie. 1975, 57, 1281. 
42. G. Dardelle, A. Subramaniam, V. Normand, Soft Matter 2011, 7, 3315.

43. S. Farris, J. Song, Q. Huang, J. Agric. Food Chem. 2010, 58, 998-1003.

44. S. Matsuda, H. Iwata, N. Se, Y. Ikada, J. Biomed. Mater. Res. 1998, 45, 20-27.

45. J.F. Martucci, A.E.M. Accareddu, R.A. Ruseckaite, J. Mater. Sci. 2012, 47, 3282-3292.

46. A. Talebian, S.S. Kordestani, A. Rashidi, F. Dadashian, M. Montazer, Kem. Ind. 2007, 11, 537541.

47. A. Bigi, G. Cojazzi, S. Panzavolta, N. Roveri, K. Rubini, Biomaterials. 2002, 23, 4827-4832.

48. C.-A. Dai, Y.-F. Chen, M.-W. Liu, J. App. Polym. Sci. 2006, 99, 1795-1801.

49. S.Z. Mazlan, S.A. Hanifah, Int. J. Polym. Sci.2017, 2017, 1-8.

50. L.A. Gonzalez-Coronel, M. Cobas, M. de J. Rostro-Alanis, R. Parra-Saldívar, C. Hernandez-Luna, M. Pazos, M.Á. Sanromán, New Biotechnology 2017, 39, 141-149.

51. Y. Zhu, S. Kaskel, J. Shi, T. Wage, K.-H. van Pée, Chem. Mater. 2007, 19, 6408-6413.

52. M. Mogharabi, N. Nassiri-Koopaei, M. Bozorgi-Koushalshahi, N. Nafissi-Varcheh, G. Bagherzadeh, M.A. Faramarzi, Bioinor. Chem. Appl. 2012, 2012, 1-6.

53. L. Lu, M. Zhao, Y. Wang, World J. Microbiol. Biotechnol. 2007, 23, 159-166.

54. F.M. Olajuyigbe, O.Y. Adetuyi, C.O. Fatokun, Int. J. Biol. Macromol. 2019, 125, 856-864.

55. H.-F. Ma, G. Meng, B.-K. Cui, J. Si, Y.-C. Dai, Chem. Eng. Res. Des. 2018, 132, 664-676.

56. H. Sun, H. Yang, W. Huang, S. Zhang, J. Colloid Interface Sci. 2015, 450, 353-360.

57. M. Asgher, S. Noreen, M. Bilal, Inter. J. Biol. Macromol. 2017, 95, 54-62.

58. M. de Cazes, M.-P. Belleville, E. Petit, M. Llorca, S. Rodríguez-Mozaz, J. de Gunzburg, D. Barceló, J. Sanchez-Marcano, Catal. Today 2014, 236, 146-152.

59. P. Ye, Z.-K. Xu, J. Wu, C. Innocent, P. Seta, Biomaterials. 2006, 27, 4169-4176.

60. C. Simón-Herrero, M. Naghdi, M. Taheran, S. Kaur Brar, A. Romero, J.L. Valverde, A. Avalos Ramirez, L. Sánchez-Silva, J. Hazard. Mater. 2019, 376, 83-90.

61. R.M. Daniel, Enzyme and Microb. Technol. 1996, 19, 74-79. 
62. L.A. Gonzalez-Coronel, M. Cobas, M. de J. Rostro-Alanis, R. Parra-Saldívar, C. Hernandez-Luna, M. Pazos, M.Á. Sanromán, New Biotechnol. 2017, 39, 141-149. 
